\title{
Introduction: Rethinking Memory Sites and Symbolic Realms of Georgian National Identity
}

\author{
Stephen F. Jones ${ }^{\mathrm{a}}$ and Malkhaz Toria (1) ${ }^{\mathrm{b}}$ \\ ${ }^{a}$ Russian and Eurasian Studies/International Relations, Mount Holyoke College, South Hadley, the USA; \\ ${ }^{\mathrm{b}}$ School of Arts and Sciences, Ilia State University, Tbilisi, Georgia
}

The study of memory, and of history, grew alongside the nationalist revival in the 1980 s and 1990s. The bloody conflicts in the Balkans and the collapse of communism in Eastern and Central Europe, revived academic interest in nationalism, and with it an examination of how "useable pasts" could be exploited and manipulated by nationalist elites. The study of memory and its relationship to history and identity underwent a period of "creative and intensive development" in the 1990s (Tota and Hagen 2016, 1). In post-Soviet states, national identity and memory were inextricably linked to the risk of social "amnesia or forgetfulness" (Simine 2013, 14). The forgetting of history and the erasure of memory was central to Soviet life before 1991. Pierre Nora's assertion that "we speak so much of memory because there is so little of it left" (Simine 2013, 14; Nora $1989,7)$, can also describe the great anxiety experienced by Georgians to this day.

The interest in memory studies in Georgia emerged after the collapse of the Soviet Union. The new national governments (and the Orthodox Church) embarked on reviving pre-Soviet memory, constructing a new story of national beginnings, intertwined with heroic kings and saints. Bringing back "lost" historical memories became central to the domestic contest between Georgia's political parties, as well as to the reinterpretation of Georgia's relations with Russia and Europe. For example, the "silenced" memories of the Democratic Republic of Georgia (DRG) (1918-1921) became an effective mnemonic bridge, which connected the new independent state after 1991 with its democratic and pro-European predecessor. New political elites in the early 1990s instrumentalized the short-lived Georgian republic in 1918-21, whose existence was ended by the Red Army, as a foundation for the legitimate restoration of Georgia's independence in 1991. Historical analogy was a mnemonic tool which represented Russia (and not just the Soviet Union) as a historical aggressor and occupier. However, in the 2000s, the DRG was forgotten once more, this time the victim of a neo-liberal ideology which rejected the DRG's social democratic foundations (Jones 2021). But during the RussoGeorgian war in 2008, parallels between the Soviet Russian occupation in 1921 and the attack in 2008 were reiterated in the media to aid the mobilization of national sentiments around the common threat to the country's territorial integrity (Toria 2014). The DRG was revived as a "usable past."

CONTACT Malkhaz Toria malkhaz_toria@iliauni.edu.ge

This work was supported by the Shota Rustaveli National Science Foundation: [Grant Number N FR17_624].

(c) 2021 International Association for the Study of the Caucasus 
Integral to the "revision" of Soviet history in Georgia, as in all the ex-Soviet republics, was the question of how to remember the twentieth century repressions and purges which devastated Georgian society from the 1920s through to the 1950s (Margvelashvili et al. 2012). How historical figures were evaluated, remembered, rehabilitated, or vilified became a crucial element of Georgia's memory politics throughout the 1990s and 2000s. The official narrative guided Georgian society, selecting who should be the new heroes, and who the villains in the new national history (Gugushvili, Kabachnik, and Kirvalidze 2017). The gallery of national heroes, includes the first president of Georgia, Zviad Gamsakhurdia (1939-1993), Ilia Chavchavadze (1837-1907), sanctified as the founding father of the modern Georgian nation, and Catholicos-Patriarch of Georgia, Ilia II, the leader of the powerful Georgian Orthodox Church (GOC). The candidates for infamous villains include Joseph Stalin (1878-1953) and, in particular, Sergo Ordzhonikidze (18861937), the Soviet leaders who orchestrated the Soviet invasion of Georgia in 1921. In the context of more recent history, Eduard Shevardnadze (1928-2014), the former foreign minister of the Soviet Union, Georgian communist party head, and later president of independent Georgia (1992-2003), is often depicted as the villainous instigator of a coup-d'etat against Zviad Gamsakhurida, and as the incompetent loser of the war against Abkhazian secessionists in 1993.

The failures and successes of almost three decades of nation-building efforts since the country's independence in 1991 supplied historians, journalists, and politicians with the thematic repertoire and conceptual apparatus with which to reinterpret Georgian history. Georgian scholars now discuss the "uses and abuses of the past" in times of civil war, ethnic conflict, and revolution. Contemporary struggles between liberal and conservative segments of society, discussions of geopolitics, the confrontation with Russia, and policy toward Stalin and his legacy, cannot be disentangled from the past. Most commonly, Georgian scholars reflect on the structure of current Georgian historical knowledge and collective memory in connection with the genealogy of modern Georgian nationalism since the nineteenth century. They describe how the Georgian "narrative template" (Wertsch and Batiashvili 2011) and "master narrative" (Chikovani 2012) shape and function in the framework of Russian imperial, Soviet imperial, and post-Soviet, memory conjunctures. The contemporary Georgian national narrative highlights the antiquity of Georgia's national history, the indigenous roots of Georgian culture in the South Caucasus, the role of the Christian faith, and Georgia's democratic traditions and Europeanness. The historical struggles with Russia, which always seeks to end the independence of Georgia and undermine its territorial integrity, are central to the new narrative. This "underlying general storyline is used repeatedly to make sense of multiple specific events" (Wertsch and Karumidze 2009, 380) and provides Georgian society with an interpretative framework to make sense of the past, its connection to current developments and to future directions.

Creating new sites of memory and destroying or reconfiguring Soviet sites, are ways of institutionalizing the new national narrative, and they have been central themes of inquiry in memory studies in Georgia. The Museum of Soviet Occupation in the framework of Georgian National Museum, the Monument of Heroes in Tbilisi, the re-conceptualized Pantheon on Mtatsminda (Tbilisi's "Holy Mountain”) (Kekelia 2016), and other symbolic "sites of persuasion" (Apsel and Sodaro 2019) now symbolize Georgians' history of struggle and sacrifice for independence rather than union with the brotherly 
peoples of the Soviet Union. This new infrastructure of collective memory instructs both Georgian citizens and foreign visitors how to distinguish the occupied from the occupier, victims from perpetrators, and collaborators from powerless bystanders (Toria 2019; Batiashvili 2015).

History teaching has become central to this project of re-memorization. History textbooks must now convey the official narrative to pupils in public schools. The post-Rose Revolution reforms in the educational system, the new law on education (2005) and national curriculum (2008-2009) were steps forward regarding the "democratization of the past" (Nora 1989). Reforms attempted to set a more neutral tone of narration. Claims that the Georgian people were always victims of external forces were discouraged; Georgia's role in global history was examined more thoroughly; and ethnic minorities' participation in the creation of Georgia was acknowledged. But these reinterpretations are under dispute and often resisted. Many school teachers and a significant number of historians are not ready to accept this more inclusive and multicultural model. For them, this new template does not spark patriotic sentiments among pupils. The distinction between the new history and preferred memories remains blurred (Chikovani 2016; Reisner and Medzmariashvili 2014; Kakitelashvili 2009). Georgian textbooks also serve as examples of silencing the past. This is true of events in the Abkhazian war (1992-1993). Silencing is a self-sufficient, and a deliberately selected technique of remembering (Bursulaia 2020).

Despite a state-sponsored policy implementing the new narrative, the Georgian mnemonic community persists with internal "conflicts and divisions" (Nora 1996) on what to remember or forget. Bivocality is an essential characteristic of a nation's historical imagination - it is a discursive structure of narratives on how "Georgianness" is imagined and perceived, located somewhere between "self-idealization" and "self-condemnation" (Batiashvili 2018). The remaining members of the Soviet generation of "intelligentsia" and "liberal intellectuals" promote mutually exclusive visions on the historical experience of the Russian-Georgian relationship and Georgia's geopolitical belonging. The former nurture an idealized image of "Georgian nationhood," often devoid of any specific focus on independence, but imagined as a nation of cultural exceptionalism. Liberal intellectuals see Georgia, rather, as a Europeanized democratic nation-state (Batiashvili 2019). The "rotating image" of Russia, Tsarist and Soviet in Georgian collective memory reveals how changing political conjunctures influence the image of Russia in Georgian society. Perception of Russia as an enemy or an ally, a "saviour" or an "aggressor," are still central to debates among Georgians in a changing world where Russia, globalization, and Europe have emerged as, alternatively, threats or buttresses to Georgian national values (Chikovani and Kakitelashvili 2015).

There are multiple contradictions in Georgian society regarding remembering and forgetting the Soviet past. Stalin is still perceived by many Georgians (reflected in the debate over what to do with his statues) as a "great Georgian," victorious in World War II, and a representation of an uncomplicated and "prosperous" life in Soviet times. Generational differences in remembering and evaluating Stalin play an important role (Kirvalidze 2014). Georgian national narratives clash with counter-narratives of Abkhaz and Ossetian minorities that go beyond Georgia's internal mnemonic struggles. All sides instrumentalize history to claim ownership of Abkhazia and South Ossetia/ 
Tskhinvali region. The "war of historians" preceded the Georgian-Abkhaz and GeorgianOssetian conflicts in the 1990s (Toria et al. 2019).

This special issue of Caucasus Survey is a collaborative endeavour of Georgian scholars to analyse and reflect on the construction of Georgian national identity, focusing on the themes above, and on the sites and realms of memory (Nora 1989). The authors worked together on the research project "Georgian National Identity and Memory Sites: Construction of the Past from Dominant and Alternative Perspectives," funded by the Shota Rustaveli National Science Foundation (SRNSF) in 2018-2021. The research team consisted of scholars affiliated with Ilia State University (the host institution) and I. Javakhishvili Tbilisi State University (co-participant). The participants are specialists in different fields of the humanities and social sciences (history, politics, sociology, cultural studies, and comparative literature). It is an important and innovative multi-disciplinary study.

The inspiration and point of departure for this collection is Pierre Nora's monumental and ground-breaking work, Les Lieux de Mémoire (1984-1992). Nora brought prominent French scholars together to explore sites of memory (lieux de mémoire), the places where a nation's collective "memory crystallizes and secretes itself" (Nora 1989, 7). According to Nora, memory in contemporary times differs from the pre-industrial, or "spontaneous" (Nora 1989, pp. 9;12) and "true" memory (Nora 1989, p. 13) of French peasant culture which took "refuge in gestures and habits, in skills passed down by unspoken traditions, in the body's inherent self-knowledge, in unstudied reflexes and ingrained memories [...]" (Nora 1989, p. 13). Today, collective memory is "seized" and institutionalized by history, leading to a professional reconstruction of the past. In Nora's words, "what we call memory today is therefore not memory but already history" (Nora 1989, p. 13). The realms of memory consist of broad, complex, symbolically charged, tangible and intangible sites of memory. This includes state symbols (mottos, emblems, anthem, coats of arms); geographical places (cities, streets, squares; battlegrounds), historical figures (national heroes, kings, "founding fathers"); historical events; repositories of national history (museums and archives); canonical works and textbooks; memorial and commemorative sites (pantheons, monuments, statues,); collective national and cultural practices (religious rituals, customs, traditions); national art (literature, poetry, songs, dance); and traditional cuisine and feasts.

This special issue deals with the symbolic sites and markers which structure Georgian society's historical consciousness and collective memory. Irakli Chkhaidze and Ketevan Kakitelashvili focus on the representation of Ilia Chavchavadze as the "father" of the Georgian nation, while Nino Chikovani investigates the significance of the Mtatsminda pantheon in Tbilisi, where the "gifted sons and daughters" of the nation are buried. Elene Kekelia and Oliver Reisner analyze the contestation over monuments of Stalin in Georgia, and Malkhaz Toria and Bejan Javakhia probe the way in which the historical events surrounding King David the Builder are used to reinforce the claims for Georgian territorial integrity. The preservation of national identity among the Georgian diasporas in the USA and Germany - through various cultural practices and memory sites - is studied by Maia Araviashvili and Konstantine Ladaria.

Each contribution in this issue adds to an overall interdisciplinary framework. The articles speak to each other and represent Georgian realms of memory as a complex and interconnected symbolic structure. There are intersections of issues, concepts, and 
theoretical approaches which, we hope, leads to meaningful explanations of modern Georgian historical knowledge, collective memory, and national identity.

The authors employ a genealogical approach to explore the "infrastructure" of Georgian collective memory; they investigate critical moments in the rise and dynamics of modern Georgian nationalism from the second half of the nineteenth century to contemporary times. This allows us to compare the nature of memory-making under four different political regimes - under tsarist rule (1801-1917); during the brief period of state building by the Democratic Republic of Georgia (1918-1921); through the traumatic transformations of the Soviet period (1921-1991); and finally in our time - the post-Soviet epoch of renewal and memory reconstruction. Each period represented a specific "regime of memory" (Radstone and Hodgkin 2003) which determined what and how Georgian society should remember or forget. This collaborative research project attempts to examine and deconstruct the structural and epistemological preconditions of the interrelations between history, memory, and identity-making in the Georgian context. Pierre Nora calls this sort of endeavour a "history of history." This differs drastically from positivist historiography, which attempts to create an "objective" record of national development or as Nora puts it, an "automatic deepening of memory, the reconstitution of a past without lacunae or faults” (Nora 1989, 9).

Irakli Chkhaidze and Ketevan Kakitelashvili's contribution deals with the representation over time of the Georgian public figure Ilia Chavchavadze (1837-1907). Paradoxically, it was not until the Soviet period that Chavchavadze, a Georgian nobleman and supporter of Georgia's national cultural rights, was given his untouchable iconic status as the founder of modern Georgian nationhood. Chavchavadze became a useful instrument - and one with multiple purposes over time - for shaping the modern Soviet Georgian nation. The image of "Ilia" as he is referred to by most Georgians, so familiar is he as the embodiment of Georgianness, grew out of a Soviet-era template of national progressive figures in each Soviet republic, union or autonomous, who symbolized the beginnings of a prescribed form of socialist nationhood. The authors show - in the framework of memory studies - how "Ilia" was manipulated by different regimes in the twentieth and twenty-first centuries to legitimize their power and make their political claims for legitimacy. Ilia Chavchavadze did not always hold this iconic position as the "father" of the nation. During the period of the social democratic government of the Democratic Republic of Georgia, he was displaced by Noe Jordania, the head of the first Georgian republic. The Soviet treatment of "Ilia" varied, according to the changing demands of the Soviet state. Before his rise in the 1930s as Georgia's progressive, but non-threatening national tutor, he was characterized as an apologist of Georgian nationalism and Georgian feudal interests. However, he was reassessed in the 1930s as a unifier, who led the Georgian intelligentsia's struggle for modernity, revolution, and equality. The authors show how the Soviet state, through print, education and film, transformed Chavchavadze into a canonical memory site of Georgian allegiance to the Soviet model of a brotherhood of progressive nations.

Nino Chikovani's contribution reflects on the construction and institutionalization of one of the major memory sites in Georgia: the Pantheon of Writers and Public Figures in Tbilisi on Mtatsminda mountain. In the final decades of the nineteenth century, creating a cemetery for distinguished Georgians in Tbilisi, which later under Soviet rule became a pantheon of famous Georgian figures, was an essential part of the complex initiative of 
public intellectuals to shape Georgian national identity. They were probably inspired by the Pantheon in Paris designed for the glorification of France's "Great Men," but it was only in 1929 that the Soviet government officially established the Mtatsminda Pantheon. The Pantheon was part of the Soviet Union's indigenization campaign, which promoted non-Russian cultures within the Union along with the "friendship among peoples" living in the Soviet state. It deepened Georgian national consciousness, though the focus was on an unpoliticized from of national-cultural identity. After the collapse of the Soviet Union and the emergence of independent Georgia, the Soviet past was characterized as a period of occupation, and the Mtatsminda Pantheon reflected the newly independent state's rewriting of history. It transformed Mtatsminda into a site of national heroes honoured for their resistance to Soviet rule. In parallel with the intombing of new national heroes, the graves of Soviet-era figures responsible for the "Sovietisation" of Georgia were transferred out of the Pantheon. Chikovani argues that the Pantheon remains a symbolic repository of Georgian national identity and collective memory in the current social and political context.

Elene Kekelia and Oliver Reisner's study of Stalin as a contested memory site, likewise, deals with the contest over memory. The dissolution of the Soviet Union and the destruction of Soviet ideology triggered questions around commemorations and created public debate over Joseph Stalin and the Soviet past. The ambivalence over Stalin's statues in Georgia underlines the political and cultural specifics of national memory. Georgia differs from other post-Soviet countries in attitudes toward Stalin - due in large part to his Georgian origins. Kekelia and Reisner, based on the debates about the restoration, removal, and defacement of Stalin monuments which began around 2012 when a new government - the "Georgian Dream" - came to power, point to the persistent identification of Stalin with a sense of lost Georgian glory and status. There were concerns about the new government's tacit acceptance or even support of the revival of the nostalgic memories of the Soviet past. What to do with the Stalin monuments reflected a political debate about the present more than it did about the past.

These debates sparked a group of activists to paint Stalin's newly restored and erected monuments pink in the rural regions in Eastern Georgia. These acts were characterized as either vandalism or as a well-deserved treatment of the Soviet totalitarian leader. The narrative of the Stalin cult broke up into two directions: the positive one feeding on Stalin's iconic cult as the son of a small but great Georgian nation, of a man who defeated the Nazis and outwitted Roosevelt and Churchill, and the pink negative one, presenting him as a brutal figure fit for humiliation and emasculation (hence the colour pink). The article shows that the conflict is not necessarily generational. Local youth in the villages where Stalin's monuments re-emerged, and shared positive attitudes toward the Soviet leader. The authors underline the mechanisms of communicative memory in local settings, which are often more powerful than those carried by social or national media. The Georgian Dream government largely ignored the debate. This indifference by the state reflects a desire not to disrupt the past. Excavating memories of those purged in the 1930s, and with them the legacy of Stalin, would undoubtedly raise questions of accountability and culpability in the present, and sharpen relations with both Russia and Georgian civil society.

Malkhaz Toria and Bejan Javakhia in their article examine the development of the narrative of the "miraculous victory" of medieval Georgian King David IV the Builder over 
the Seljuk Turks in the Battle of Didgori in August 1121, and the subsequent "liberation" of Tbilisi from Arab Muslims. They argue that this narrative is used to reinforce the trope of Georgian territorial integrity in the Georgian historical collective memory. The authors follow concrete historiographical "shifts" and "regimes of memory" to show how and why this narrative became a central element in the Georgian "realms of memory" (Nora 1989). In this genealogical approach, Toria and Javakhia show how one of David's court historians in the twelfth century envisaged the realization of God's divine plan in the "miraculous victory" in the Battle of Didgori. In the wake of Russian revolutions and during the short-lived Democratic Republic of Georgia (19181921), David's image as a great historical character began to take form in the context of modern Georgian nationalism. The Soviet period was the first formative moment when the history and memory of David and Didgori became intertwined with Georgian territorial nationalism. The "progressive" and integrative Soviet nationality policy, which aimed to form an ethno-federal union of "sovereign" Soviet socialist republics, drew on the image of David the Builder as a promoter of Georgian unification along with tolerance of brotherly peoples. In the post-Soviet "nationalizing state" (Brubaker 2004), ethnoreligious nationalism added to the re-sacralization of David. He moved into the realm of the sacred, a form of national memory tied to the newly powerful Georgian Orthodox Church in the post-Soviet period. The loss of Georgian government control over the breakaway regions of Abkhazia and South Ossetia/Tskhinvali region in the 1990s added to the fertile soil for the narrative of David and Didgori. These fateful and glorious moments in national history invoked hopes in contemporary Georgia for the restoration of Georgia's territorial integrity.

Maia Araviashvili and Konstantine Ladaria in their contribution reflect on how Georgian immigrant communities in the USA (New York City) and Germany (Berlin and Regensburg) create and reproduce sites of national memory while separated from their homeland. Georgian immigrant communities in the USA and Germany were in existence before the end of the Soviet Union, but the collapse of the Soviet state, and the new reach of globalization gave a new impetus to modes of cultural self-preservation within larger "foreign" states. Georgian immigrants consisting of "old" and "new" arrivals, multiple generations, and varied employment backgrounds exposed the complexity of Georgian diasporas as they attempted to both integrate and preserve their difference within host societies. The fieldwork, which included interviews and surveys in Germany and the USA, revealed interesting differences between Georgian immigrants who envisaged returning home in contrast to those planning on remaining. Those wishing to return shared a more conservative approach to communal traditions and customs. They were more sensitive to the dilemma of integration into the host society versus maintaining national memories and connections to the homeland. The authors show how Georgian immigrants in the USA and Germany preserve their Georgianness through real-life and virtual social spaces, where they cultivate tangible and intangible "memory sites" such as the Georgian language, Georgian books for a home library, attendance at Georgian Sunday schools, Georgian dance classes, and the preservation of Georgian cuisine and feasting customs. The church plays a special role as a memory link to a Georgian past beset with external cultural threats. Attending services in Georgian churches, celebrating religious holidays, and creating "icon corners" at home are all methods for dealing with the isolation from home. 


\section{Disclosure statement}

No potential conflict of interest was reported by the author(s).

\section{ORCID}

Malkhaz Toria (D) http://orcid.org/0000-0003-1221-2361

\section{References}

Apsel, Joyce, and Amy Sodaro. 2019. Museums and Sites of Persuasion: Politics, Memory and Human Rights. 1st edition. New York: Routledge.

Batiashvili, Nutsa. 2015. "What Are Sites of Memories For?" Paper for the Conference "Sites of Memory of Socialism and Communism in Europe, September 2015.

Batiashvili, Nutsa. 2018. The Bivocal Nation: Memory and Identity on the Edge of Empire. Cham, Switzerland: Palgrave Macmillan. doi:10.1007/978-3-319-62286-6.

Batiashvili, Nutsa. 2019. "Power/Memory: New Elite, Old Intelligentsia, and Fixing of the Georgian Mind.” Nationalities Papers 47 (6): 1083-1099. doi:10.1017/nps.2019.29.

Brubaker, Rogers. 2004. Ethnicity Without Groups. Cambridge, Mass: Harvard University Press.

Bursulaia, Guranda. 2020. "The Voices of Silence: The Case of Georgian History Textbooks." Caucasus Survey 8 (3): 278-293. doi:10.1080/23761199.2019.1709784.

Chikovani, Nino. 2012. "The Georgian Historical Narrative: From pre-Soviet to Post-Soviet Nationalism." Dynamics of Asymmetric Conflict: Pathways Toward Terrorism and Genocide 5 (2): 107-115.

Chikovani, Nino. 2016. "Ethnic Minorities in the History of Georgia: The Post-Soviet History Textbooks." In Exchange, Dialogue, New Divisions?: Ethnic Groups and Political Cultures in Eastern Europe, edited by Sonya Schuler, 45-55. Freiburg Studies in Social Anthropology I Freiburger Sozialanthropologische Studien 45. Zürich: LIT Verlag.

Chikovani, Nino, and Ketevan Kakitelashvili. 2015. "Fluctuating Memory: Rotating Images of the 'Big Brother' and 'Aggressor'.” Kyлmypa/Culture [S.l.] n. 10 (September): 130-139.

Gugushvili, Alexi, Peter Kabachnik, and Ana Kirvalidze,. 2017. "Collective Memory and Reputational Politics of National Heroes and Villains." Nationalities Papers 45 (3): 464-484. doi:10.1080/00905992.2016.1261821.

Jones, Stephen F. 2021. "The Democratic Republic of Georgia, 1918-21.” In Language and Society in the Caucasus Understanding the Past, Navigating the Present, edited by Christofer Berglund, Katrine Gotfredsen, Jean Hudson, and Bo Petersson, 126-146. Lund: Universus Press.

Kakitelashvili, Ketevan. 2009. "Instrumentalization of History and History Teaching in Post-Soviet Georgia." tsivilizadtsiuri dziebani [Civilization Researches] N 7, 24-28.

Kekelia, Elene. 2016. "The Formation and the Legacy of the Mtatsminda Pantheon as a Site of Memory." Identity Studies in the Caucasus and the Black Sea Region 7: 41-63.

Kirvalidze, Ana. 2014. "Soviet Memory in the Process of National Identity Formation: The Case of Georgia Conceptual Links Between Identity and Memory." Identity Studies in the Caucasus and the Black Sea Region 5: 17-29.

Margvelashvili, Ana, Irakli Khvadagiani, Giorgi Shaishmelashvili, and Magda Tsotskhalashvili. 2012. dakarguli istoria: mekhsiereba represirebuli kalebis shesakheb [Lost History: Memory of the Repressed Women]. Tbilisi: Sovlab.

Nora, Pierre. 1989. "Between Memory and History: Les Lieux de Mémoire.” Representations 26: 724.

Nora, Pierre. 1996. Realms of Memory: Rethinking the French Past, Vol. 1 - Conflicts and Divisions. Subsequent edition. New York: Columbia University Press.

Radstone, Susannah, and Katharine Hodgkin, eds. 2003. Regimes of Memory. London and New York: Routledge. 
Reisner, Oliver, and Elene Medzmariashvili. 2014. "The Implications of Cultural and Religious Diversity for History Education in Georgia.” In Историята, Която Усмихва [The History That Makes Us Smile: In Memoriam of Prof. Rumyana Kusheva], edited by Violeta Stojčeva, 298-313. Sofia: Paradigma.

Simine, Silke Arnold-de. 2013. "Memory Boom, Memory Wars and Memory Crises." In Mediating Memory in the Museum: Trauma, Empathy, Nostalgia. Palgrave Macmillan Memory Studies, edited by Silke Arnold-de Simine, 14-19. London: Palgrave Macmillan UK. doi:10.1057/ 9781137352644_3.

Toria, Malkhaz. 2014. "The Soviet Occupation of Georgia in 1921 and the Russian-Georgian War of August 2008: Historical Analogy as a Memory Project." In The Making of Modern Georgia, 1918-2012: The First Georgian Republic and Its Successors, edited by Stephen F. Jones, 316-336. London and New York: Routledge, Taylor \& Francis Group.

Toria, Malkhaz. 2019. "Between Traditional and Modern Museology: Exhibiting National History in the Museum of Georgia." In Museums and Sites of Persuasion. Politics, Memory and Human Rights, edited by Joyce Apsel, and Amy Sodaro, 39-54. London and New York: Routledge, Taylor \& Francis Group.

Toria, Malkhaz, Nino Pirtskhalava, Elene Kekelia, and Konstantine Ladaria. 2019. "Trapped in the Past: Memories of Georgian Internally Displaced Persons on the Margins of Society." Nationalities Papers 47 (3): 429-444. doi:10.1017/nps.2018.34.

Tota, Anna Lisa, and Trever Hagen. 2016. "Introduction: Memory Work: Naming Pasts, Transforming Futures.” In Routledge International Handbook of Memory Studies, 1st Edition, edited by Anna Lisa Tota, and Trever Hagen, 1-6. Abingdon/New York: Routledge.

Wertsch, James V., and Nutsa Batiashvili. 2011. "Mnemonic Communities and Conflict: Georgia's National Narrative Template." In Trust and Conflict, edited by Ivana Marková, and Alex Gillespie, 37-48. London and New York: Routledge.

Wertsch, James V., and Zurab Karumidze. 2009. "Spinning the Past: Russian and Georgian Accounts of the War of August 2008." Memory Studies 2 (3): 377-391. doi:10.1177/ 1750698008337566. 